\title{
Futile substrate cycles in the glycolytic pathway of boar and rat spermatozoa and the effect of $\alpha$-chlorohydrin
}

\author{
W. C. L. Ford* and A. Harrison \\ Department of Physiology \& Biochemistry, The University, Whiteknights, Reading RG6 2AJ, U.K.
}

\begin{abstract}
Summary. In boar spermatozoa incubated with $0.1 \mathrm{~mm}$-glucose about $20 \mathrm{nmol}$ glucose were converted to lactate and $\mathrm{CO}_{2}$ and the rate of futile substrate cycling between glucose and glucose 6 -phosphate was about $6 \mathrm{nmol} / 10^{8}$ spermatozoa $/ 30 \mathrm{~min}$. Futile cycling was increased in the presence of 0.05 or $1 \mathrm{mM}-\alpha$-chlorohydrin but not to an extent sufficient to account for the rapid decline in ATP concentration observed under these conditions. These estimates include a substantial rate of fructose formation from fructose phosphates. The addition of $10 \mathrm{mM}$-L-lactate plus $1 \mathrm{~mm}$-pyruvate protected the spermatozoa against the effect of $\alpha$-chlorohydrin and glucose on the ATP concentration but increased futile substrate cycling. Substrate cycling between fructose 6-phosphate and fructose 1,6-bisphosphate could not be measured in boar spermatozoa but in rat spermatozoa its rate $\left(\mathrm{nmol} / 10^{8}\right.$ spermatozoa/30 min) was about 10 under control condition and about 25 in the presence of $1 \mathrm{~mm}-\alpha$-chlorohydrin. This increase was insufficient to account for the decline in ATP concentration. In both species futile substrate cycling consumed a significant proportion of the ATP synthesis during lactate production but only about $5 \%$ of that produced in the oxidation of glucose to acetyl carnitine and $\mathrm{CO}_{2}$.
\end{abstract}

\section{Introduction}

a-Chlorohydrin and the 6-chloro-6-deoxysugars have a rapid and reversible antifertility effect on male animals from several species (see Ford, 1982; Jones, 1983). This is associated with the inhibition of glyceraldehyde 3-phosphate dehydrogenase [EC 1.2.1.12] in spermatozoa but the effect of this is more complex than simply to prevent the metabolism of sugars through the glycolytic pathway. For example, when spermatozoa from rams, rats or boars were incubated with $1 \mathrm{~mm}-\alpha-$ chlorohydrin in the absence of glycolysable sugars they remained motile and sustained a high ATP concentration for some time but when glucose was added there was a rapid and substantial decline in the concentration of ATP and in motility (Ford \& Harrison, 1985). Under a variety of conditions the decrease in ATP was always accompanied by a concomitant increase in the concentration of fructose 1,6-bisphosphate. Fructose 1,6-bisphosphate never accumulated when there was no decline in ATP (Ford \& Harrison, 1986).

Futile substrate cycling between glucose and glucose 6-phosphate and between fructose 6phosphate and fructose 1,6-biphosphate has been demonstrated in several tissues. In liver and kidney it may be an unavoidable consequence of retaining the capacity for both glycolysis and gluconeogenesis but the process may also have useful physiological functions, e.g. heat production and improving the sensitivity of metabolic regulation (see Katz \& Rognstad, 1976; Newsholme \& Crabtree, 1976; Hue, 1981; Newsholme et al., 1983). Futile substrate cycles occur in bull spermatozoa and significantly decrease the efficiency of ATP production from glucose metabolism

*Present address: University Department of Obstetrics \& Gynaecology, Bristol Maternity Hospital, Southwell Street, Bristol BS2 8EG, U.K. 
(Hammerstedt \& Lardy, 1983; Inskeep \& Hammerstedt, 1985). However, the hydrolysis of glucose 6-phosphate and of fructose 1,6-bisphosphate in spermatozoa is catalysed by non-specific phosphatases rather than by glucose 6-phosphatase [EC 3.1.3.9] and fructose bisphosphatase [EC 3.1.3.11] and it is doubtful if substrate cycling in these cells has a physiological role.

In spermatozoa exposed to $\alpha$-chlorohydrin and glucose, the low concentration of ATP and the high concentration of AMP and fructose 1,6-bisphosphate will activate phosphofructokinase [EC 2.7.1.11] (Hoskins \& Stephens, 1969). The high concentration of fructose 1,6-bisphosphate will favour its hydrolysis by non-specific phosphatases and the conditions might permit very rapid futile cycling between fructose 6-phosphate and fructose 1,6-bisphosphate. It is possible that this could consume sufficient ATP to explain the rapid loss of ATP when glucose is added to spermatozoa in the presence of $\alpha$-chlorohydrin.

The experiments described below were done to test this hypothesis and to determine whether futile substrate cycling occurs in spermatozoa from species other than the bull

\section{Materials and Methods}

Materials and spermatozoa. The sperm-rich fraction of boar semen was donated generously by the Ministry of Agriculture, Fisheries and Food, Pig Breeding Centre, Shinfield, Reading. Rats of the CD-strain were obtained from Charles River U.K., Ltd, Margate CT9 4LT, U.K. Spermatozoa were prepared as described previously, except that rat spermatozoa were allowed to disperse naturally with gentle shaking rather than being sucked in and out of a Pasteur pipette (Ford et al., 1981; Ford \& Harrison, 1985). D- $\left[\mathrm{U}-{ }^{14} \mathrm{C}\right]$ glucose, D- $\left[2-{ }^{3} \mathrm{H}\right]$ glucose, D- $\left[3-{ }^{3} \mathrm{H}\right] \mathrm{glucose}$, DL- $\left[1-{ }^{14} \mathrm{C}\right]$ lactate and tritiated water were purchased from Amersham International plc, Amersham HP7 9LL, U.K. The tritiated glucose was subjected to several cycles of sublimation before use to remove traces of tritiated water $\left({ }^{3} \mathrm{HOH}\right)$. Enzymes, biochemicals and Dowex ion exchange resins were obtained from Sigma Chemical Co., Ltd, Poole BM17 7NH, U.K. $R S$ - $\alpha$-Chlorohydrin was supplied by Koch Light Ltd, Colnbrook SL3 0BZ, U.K., and was redistilled under reduced pressure before use. Other reagents were obtained from Fisons Scientific Apparatus, Loughborough, LE11 0RG, U.K.

Incubations. These were done in $10-\mathrm{ml}$ conical flasks in a shaking water bath at $34^{\circ} \mathrm{C}$ with air as the gas phase and were organized in a similar way to previous experiments (Ford et al., 1981; Ford \& Harrison, 1986). The incubation period with $\alpha$-chlorohydrin before the addition of substate was $10 \mathrm{~min}$ for boar and $30 \mathrm{~min}$ for rat spermatozoa. The concentration of spermatozoa $\left(\times 10^{6} / \mathrm{ml}\right.$ : mean \pm s.e.m. $)$ was $145 \pm 7 \cdot 6(n=11$; boar $)$ and $118 \pm 11 \cdot 3(n=7$; rat $)$.

Separation of radioactively labelled glycolytic intermediates and tritiated water. The procedures used were based on those described by Hammerstedt (1980) and by Hammerstedt \& Lardy (1983). A neutralized perchloric acid extract $(0.5 \mathrm{ml})$ was applied to the top of a stack of 3 ion-exchange columns and was washed through with $4 \times 2 \mathrm{ml}$ water. The columns (from top to bottom) were: (1) $0.6 \mathrm{ml}$ Dowex- $50 \mathrm{H}^{+}$in a 1 -ml syringe (6 $\mathrm{mm}$ i.d.), (2) $1.3 \mathrm{ml}$ Dowex-1 formate in a $2-\mathrm{ml}$ disposable syringe $(9 \mathrm{~mm}$ i.d.), (3) $0.8 \mathrm{ml}$ Dowex-1 borate in a $1-\mathrm{ml}$ syringe. All the resins were $8 \%$ cross-linked and $200-400$ mesh. The columns were packed wet and small circles of filter paper were used to retain the resins in the syringe. Flow through the columns was regulated by attaching a needle $(16 \times 0.5 \mathrm{~mm})$ with about $2 \mathrm{~cm}$ of vinyl tube $(0.2 \mathrm{~mm}$ i.d. $0.5 \mathrm{~mm}$ o.d. $)$ to the Dowex $-50 \mathrm{H}^{+}$column. The results were not affected if the columns ran dry for short periods. Acetyl carnitine was trapped on column 1 and was eluted with $4 \times 2 \mathrm{ml} 2 \mathrm{M}$ - $\mathrm{HCl}$. Hexose phosphates, fructose 1,6-bisphosphate, triose phosphates and lactate were retained in column 2 . Lactate was eluted with $3 \times 2 \mathrm{ml} 3 \mathrm{M}$-formic acid, hexose phosphates and triose phosphates were eluted with $3 \times 2 \mathrm{ml} 1 \mathrm{M}$-formic acid plus $0.3 \mathrm{M}$-ammonium formate and fructose 1,6-bisphosphate with $3 \times 2 \mathrm{ml} 1 \mathrm{M}$-formic acid plus $0.75 \mathrm{M}$-ammonium formate. Glucose was trapped on column 3 and eluted with $3 \times 2 \mathrm{ml} 0.5 \mathrm{M}$-acetic acid. Tritiated water was the only radioactively labelled compound to pass through the stack of columns. The percentages of standard $\left[\mathrm{U}-{ }^{14} \mathrm{C}\right] \mathrm{glucose}$, $\left[1-{ }^{14} \mathrm{C}\right]$ lactate and tritiated water recovered in the expected fractions were 96,94 and 97 respectively. $\left[\mathrm{U}-{ }^{14} \mathrm{C}\right] \mathrm{Glucose}$ 6-phosphate was prepared from $\left[\mathrm{U}^{-14} \mathrm{C}\right] \mathrm{glucose}$ and ATP using hexokinase and chromatographed without further purification and $62 \%$ of the radioactivity was retained in the glucose 6-phosphate fraction. The concentration of fructose 1,6-bisphosphate calculated from the radiochemical measurements $(x)$ was in very close agreement with the amount measured enzymically $(y)$ (regression equation $y=1.07 x-0 \cdot 18$ ). In the time course experiment with boar spermatozoa, $99 \cdot 6 \pm 0.5 \%$ of ${ }^{3} \mathrm{H}$ and $98.7 \pm 0.5 \%$ of ${ }^{14} \mathrm{C}$ radioactive material applied to the stack of columns was recovered in the eluants (mean \pm s.e.m., $n=51$ ). However $\leqslant 50 \%$ of the triose phosphate which was measured in an enzymic assay was recovered in the glucose 6-phosphate fraction eluted from the columns. Since none was detected in the other fractions and none could be eluted from the columns with solutions of greater ionic strength it was concluded that some of these compounds decompose during the separation procedure.

Measurement of the ${ }^{3} \mathrm{H} /{ }^{14} \mathrm{C}$ ratio in glucose 6-phosphate and fructose I,6-bisphosphate. The appropriate fractions were pooled and freeze-dried. The putative fructose 1,6-bisphosphate was incubated with fructose bisphosphatase to 
convert it to fructose 6-phosphate which was isolated by ion-exchange chromatography (Hammerstedt, 1980). The original fructose 1,6-bisphosphate fraction did not contain other radioactive substances and the ${ }^{3} \mathrm{H} /{ }^{14} \mathrm{C}$ ratio did not change as a result of the enzymic conversion to fructose 6-phosphate. Therefore the conversion was not done routinely and the isotope ratio in the original fraction was used in the calculations. Glucose 6-phosphate, together with fructose 6-phosphate, was converted to fructose 1,6-bisphosphate. The dried fractions were taken up in $1 \mathrm{ml} 50 \mathrm{~mm}$-Tris $\mathrm{HCl}$, $5 \mathrm{mM}-\mathrm{MgCl}_{2}, 50 \mathrm{~mm}-\mathrm{KCl}, 2 \mathrm{~mm}-\mathrm{ATP}, 2 \mathrm{~mm}-\mathrm{AMP}, \mathrm{pH} 8.2$ containing 3-4 units phosphofructokinase and 10 units phosphoglucose isomerase [EC 5.3.1.9] and incubated at $34^{\circ} \mathrm{C}$ for $45 \mathrm{~min}$. The mixture was cooled to $4^{\circ} \mathrm{C}$ and fructose 1.6-bisphosphate was isolated by ion-exchange chromatography as described above. The concentration of glucose 6-phosphate in boar spermatozoa was too low to allow this procedure to be applied but the isotopic ratio in glucose 6-phosphate was measured in rat spermatozoa for each incubation condition.

Calculation of the rates of futile substrate cycling and ATP yields. The derivation of the formulae used is discussed in reviews by Katz \& Rognstad (1976) and Newsholme \& Crabtree (1976). We assumed that tritium from $\left[2 \cdot{ }^{3} \mathrm{H}\right]-$ glucose was completely liberated from the hexose 6-phosphate pool by the activity by phosphoglucose isomerase; therefore the flux through hexokinase $\left(R_{1}\right)$ is equal to the rate of production of tritiated water (Fig. 1$)$. If glucose 6-phosphate was hydrolysed by glucose 6-phosphatase alone then the rate of glucose 6-phosphate hydrolysis $\left(R_{2}\right)$ would be equal to $R_{1}$ minus the rate of production of ${ }^{14} \mathrm{C}$-labelled products from $\left[\mathrm{U}^{14} \mathrm{C}\right] \mathrm{glucose}$. However, in spermatozoa, hexose phosphates and fructose 1,6-bisphosphate were hydrolysed by non-specific phosphatases (Hammerstedt \& Lardy, 1983) and fructose may be formed by the hydrolysis of fructose 6-phosphate or by the successive hydrolysis of fructose 1,6-bisphosphate and fructose 1-phosphate. Fructose was not separated from glucose and the calculation described will give the total rate of hexose phosphate hydrolysis $\left(\mathrm{R}_{2}=\mathrm{R}_{2}^{\prime}+\mathrm{R}_{2}^{\prime \prime}+\mathrm{R}_{2}^{\prime \prime}\right)$ (Fig. 1). The $K_{\mathrm{m}}$ of hexokinase for fructose is much larger than for glucose and the fructose should not be metabolized to a significant extent whilst glucose remains in excess; the rate of hexose phosphorylation will therefore remain equal to the rate of glucose phosphorylation calculated from the release of tritiated water. The estimate of ATP consumption due to hexose monophosphate hydrolysis will therefore remain accurate.

The rates of synthesis and hydrolysis of fructose 1,6-bisphosphate $\left(R_{3}\right.$ and $R_{4} ;$ Fig. 1) were calculated from the formulae $R_{3}=T\left(1-S_{2}\right) /\left(S_{1}-S_{2}\right)$ and $R_{4}=T\left(1-S_{1}\right) /\left(S_{1}-S_{2}\right)$ where $T=$ moles $\left[{ }^{3} H\right]$ glucose converted to ${ }^{3} \mathrm{HOH}, \mathrm{S}_{1}=\left({ }^{3} \mathrm{H} /{ }^{14} \mathrm{C}\right.$ ratio of hexose phosphate) $/\left({ }^{3} \mathrm{H} /{ }^{14} \mathrm{C}\right.$ ratio of glucose $)$ and $\mathrm{S}_{2}=\left({ }^{3} \mathrm{H} /{ }^{14} \mathrm{C}\right.$ ratio of fructose 1,6-bisphosphate) $/\left({ }^{3} \mathrm{H} /{ }^{14} \mathrm{C}\right.$ ratio of glucose) (Newsholme \& Crabtree, 1976). This depends on the assumption that the specific activity of glucose 6-phosphate is similar to that of fructose 6-phosphate. Under control conditions the amount of fructose I,6-bisphosphate recovered was too small to enable its specific activity to be measured accurately and $\mathrm{S}_{2}$ was assumed to be zero.

The estimation of $R_{3}$ and $R_{4}$ will not be affected by the hydrolysis of fructose 1,6-bisphosphate to fructose 1-phosphate but if this occurs $R_{4}$ will underestimate the consumption of ATP as a result of fructose 1,6-bisphosphate hydrolysis.

The gross production of ATP was calculated as the total formed during the production of lactate, acetyl carnitine and $\mathrm{CO}_{2}$. The moles of ATP formed during the conversion of $1 \mathrm{~mol}$ glucose to product was assumed to be: lactate 2, acetyl carnitine $14, \mathrm{CO}_{2} 38$. The amount of $\mathrm{CO}_{2}$ associated with acetyl carnitine production was subtracted from the total before the ATP yield was calculated. The ATP consumed in glucose metabolism was taken as that consumed in the production of glycolytic intermediates (assuming that phosphate was transferred stoichemically) plus that con-

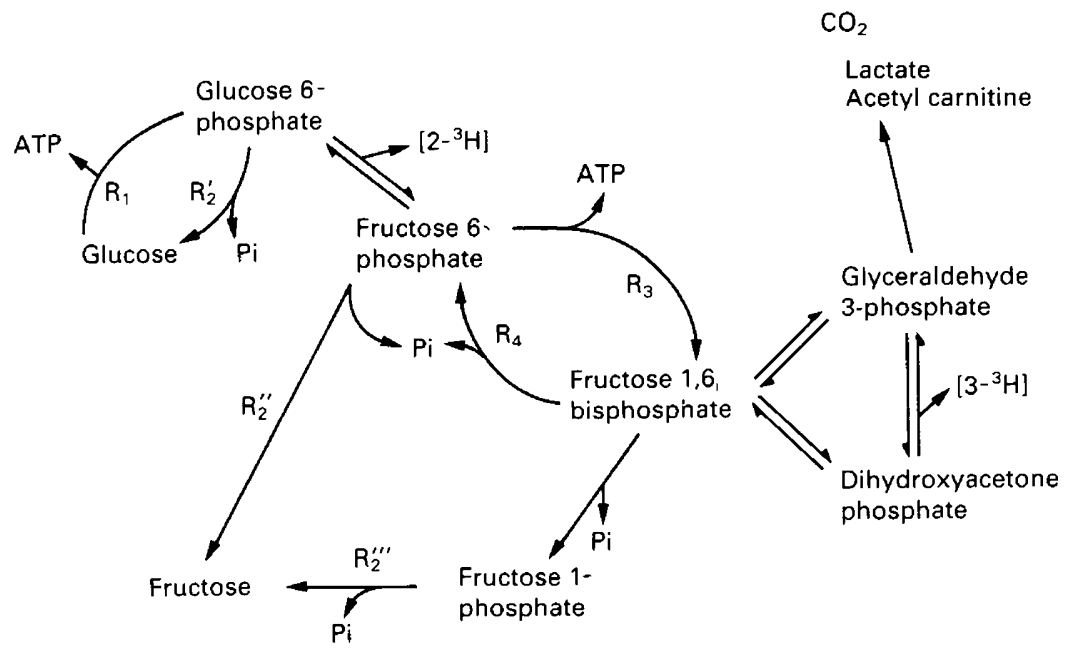

Fig. 1. Futile substrate cycles in glucose metabolism. 
sumed in futile substrate cycles. The effect of fructose 1-phosphate formation was ignored but will be subsumed in the glucose 6-phosphate calculations.

Other measurements and the evaluation of results. The concentrations of adenine nucleotides and of glycolytic intermediates were measured as described previously (Ford \& Harrison, 1981; Ford et al., 1981). The statistical significance of the differences between the treatments was evaluated by a multi-way analysis of variance and individual differences were tested by a $t$ test on the least squares means of the groups. The calculations were done with the GLM procedure of the SAS computer program (SAS Institute Inc. P.O. Box 8008, Cary, NC 27511, USA) as implemented on the University of Reading computer.

\section{Results}

\section{Preliminary experiments}

$\alpha$-Chlorohydrin at 0.05 or $1.0 \mathrm{~mm}$ inhibited the production of $\left[{ }^{14} \mathrm{C}\right]$ lactate and ${ }^{14} \mathrm{CO}_{2}$ from $0 \cdot 1 \mathrm{~mm}-\left[\mathrm{U}-{ }^{14} \mathrm{C}\right] \mathrm{glucose}$ by boar spermatozoa during incubation for $1 \mathrm{~h}$ at $34^{\circ} \mathrm{C}$ and caused the accumulation of $\left[{ }^{14} \mathrm{C}\right]$ fructose 1,6 -bisphosphate.

The net effect was to decrease the conversion of $\left[\mathrm{U}-{ }^{14} \mathrm{C}\right] \mathrm{glucose}$ to ${ }^{14} \mathrm{C}$ products. The effect of $1.0 \mathrm{~mm}$ - $\alpha$-chlorohydrin was always greater than that of $0.05 \mathrm{~mm}$ but the difference was not statistically significant (Table 1). The production of ${ }^{3} \mathrm{HOH}$ from $\left[2-{ }^{3} \mathrm{H}\right]$ glucose was not significantly affected by $\alpha$-chlorohydrin and was always greater than the production of ${ }^{14} \mathrm{C}$ products. The rate of glucose phosphorylation $\left(R_{1}\right)$ remained about $40 \mathrm{nmol} / 10^{8}$ spermatozoa irrespective of the $\alpha$-chlorohydrin concentration but the rate of glucose 6-phosphate hydrolysis $\left(R_{2}\right)$ increased 7 -fold in the presence of $\alpha$-chlorohydrin. A similar estimate of $R_{2}$ was obtained by calculating the rate of return of detritiated glucose to the glucose pool (Table 1). In addition to the errors discussed

Table 1. The metabolism of $0 \cdot 1 \mathrm{~mm}-\left[2-{ }^{3} \mathrm{H}, \mathrm{U}-{ }^{14} \mathrm{C}\right]$ glucose or $\left[3-{ }^{3} \mathrm{H}, \mathrm{U}-{ }^{14} \mathrm{C}\right] \mathrm{glucose}$ by boar spermatozoa incubated with $\alpha$-chlorohydrin for 10 min before the addition of the glucose and then for $1 \mathrm{~h}$ at $34^{\circ} \mathrm{C}$

\begin{tabular}{|c|c|c|c|c|c|c|}
\hline \multirow[b]{2}{*}{ Product } & \multicolumn{3}{|c|}{$\begin{array}{c}{\left[2-{ }^{3} \mathrm{H}, \mathrm{U}-{ }^{14} \mathrm{C}\right] \text { glucose }} \\
\text { and } \alpha \text {-chlorohydrin (mM) }\end{array}$} & \multicolumn{3}{|c|}{$\begin{array}{c}{\left[3-{ }^{3} \mathrm{H}, \mathrm{U}-{ }^{14} \mathrm{C}\right] \text { glucose }} \\
\text { and } \alpha \text {-chlorohydrin (mM) }\end{array}$} \\
\hline & $0(4)$ & $0.05(2)$ & $1 \cdot 0(2)$ & $0(5)$ & $0.05(2)$ & $1 \cdot 0(3)$ \\
\hline${ }^{3} \mathrm{HOH}$ & $\begin{array}{c}39 \\
\pm 2 \cdot 3\end{array}$ & $\begin{array}{c}39 \\
(38,40)\end{array}$ & $\begin{array}{c}34 \\
(40,29)\end{array}$ & $\begin{array}{c}40 \\
\pm 3 \cdot 1\end{array}$ & $\begin{array}{c}35 \\
(32,39)\end{array}$ & $\begin{array}{r}8^{* * *} \\
\pm 0.5\end{array}$ \\
\hline$\left[{ }^{14} \mathrm{C}\right]$ Lactate & $\begin{array}{l}29 \\
\pm 3.2\end{array}$ & $\begin{array}{c}6 \\
(6,6)\end{array}$ & $\begin{array}{c}1 \cdot 6^{*} \\
(1 \cdot 7,1 \cdot 5)\end{array}$ & $\begin{array}{l}30 \\
\pm 3 \cdot 7\end{array}$ & $\begin{array}{c}5 \cdot 9 \\
(6 \cdot 2,5 \cdot 7)\end{array}$ & $\begin{array}{r}1.9^{*} \\
\pm 0.3\end{array}$ \\
\hline$\left[{ }^{14} \mathrm{C}\right]$ Glucose-6-phosphate $\dagger$ & $\begin{array}{r}1 \cdot 1 \\
\pm 0 \cdot 3\end{array}$ & $\begin{array}{c}2 \cdot 8 \\
(2 \cdot 6,3 \cdot 0)\end{array}$ & $\begin{array}{c}2 \cdot 6^{*} \\
(2 \cdot 9,2 \cdot 3)\end{array}$ & $\begin{array}{r}1 \cdot 3 \\
\pm 0 \cdot 3\end{array}$ & $\begin{array}{c}2 \cdot 8 \\
(2 \cdot 6,3 \cdot 0)\end{array}$ & $\begin{aligned} & 2 \cdot 3 \\
+ & 0 \cdot 14\end{aligned}$ \\
\hline$\left[{ }^{14} \mathrm{C}\right]$ Fructose 1,6-bisphosphate & $\begin{aligned} & 0.2 \\
\pm & 0.05\end{aligned}$ & $\begin{array}{c}7 \cdot 1 \\
(6 \cdot 2,8 \cdot 0)\end{array}$ & $\begin{array}{c}7 \cdot 9 * * \\
(8 \cdot 4,7 \cdot 3)\end{array}$ & $\begin{aligned} & 0.1 \\
\pm & 0.04\end{aligned}$ & $\begin{array}{c}6 \cdot 1 \\
(4 \cdot 2,8 \cdot 0)\end{array}$ & $\begin{aligned} & 8.7 * * \\
\pm & 0.67\end{aligned}$ \\
\hline${ }^{14} \mathrm{CO}_{2}$ & $\begin{array}{r}6 \cdot 1 \\
\pm 1 \cdot 8\end{array}$ & $\begin{array}{c}3 \cdot 2 \\
(3 \cdot 5,2 \cdot 9)\end{array}$ & $\begin{array}{c}0 \cdot 8 \\
(0 \cdot 9,0 \cdot 8)\end{array}$ & $\begin{array}{r}4 \cdot 8 \\
\pm 1 \cdot 5\end{array}$ & $\begin{array}{c}3 \cdot 6 \\
(3 \cdot 9,3 \cdot 4)\end{array}$ & $\begin{array}{l}0.8 \\
+0.10\end{array}$ \\
\hline Total ${ }^{14} \mathrm{C}$ products & $\begin{array}{l}37 \\
\pm 2 \cdot 7\end{array}$ & $\begin{array}{l}19 \\
(18,20)\end{array}$ & $\begin{array}{l}13^{*} \\
(14,12)\end{array}$ & $\begin{array}{c}36 \\
\pm 33\end{array}$ & $\begin{array}{l}19 \\
(20,17)\end{array}$ & $\begin{array}{r}14 * * \\
\pm 0.55\end{array}$ \\
\hline Tritiated water - total $^{14} \mathrm{C}$ & $\begin{array}{r}2.9 \\
+1.0\end{array}$ & $\begin{array}{c}20 \\
(20,20)\end{array}$ & $\begin{array}{c}22^{*} \\
(26,17)\end{array}$ & 二 & - & 二 \\
\hline$\left[{ }^{3} \mathrm{H}\right]$ Glucose utilized & $\begin{array}{l}46 \\
\pm 2 \cdot 7\end{array}$ & $\begin{array}{c}43 \\
(39,48)\end{array}$ & $\begin{array}{c}38 \\
(44,32)\end{array}$ & $\begin{array}{l}45 \\
\pm 3.0\end{array}$ & $\begin{array}{c}41 \\
(37,46)\end{array}$ & $\begin{array}{l}20^{* *} \\
\pm 1 \cdot 0\end{array}$ \\
\hline$\left[{ }^{14} \mathrm{C}\right]$ Glucose utilized & $\begin{array}{c}44 \\
\pm 1 \cdot 3\end{array}$ & $\begin{array}{c}28 \\
(24,31)\end{array}$ & $\begin{array}{r}18^{* * *} \\
(17,18)\end{array}$ & $\begin{array}{c}44 \\
\pm 3 \cdot 2\end{array}$ & $\begin{array}{c}29 \\
(28,30)\end{array}$ & $\begin{array}{c}17^{* *} \\
\pm 1 \cdot 0\end{array}$ \\
\hline$\left[{ }^{3} \mathrm{H}-{ }^{14} \mathrm{C}\right]$ Glucose & $\begin{array}{r}1.9 \\
\pm 2.2\end{array}$ & $\begin{array}{c}16 \\
(15,17)\end{array}$ & $\begin{array}{c}21^{* *} \\
(27,14)\end{array}$ & 二 & - & 二 \\
\hline
\end{tabular}

Values are nmol glucose metabolized $/ 10^{8}$ spermatozoa and are means \pm s.e.m. for the no. of observations in parentheses.

Significant effect of $\alpha$-chlorohydrin: ${ }^{*} P<0.05 ;{ }^{* *} P<0.01$; ${ }^{* *} P<0.001$ (analysis of variance).

$\dagger$ Includes some triose phosphates. 
elsewhere, these data are uncorrected for the decrease in the specific activity of $\left[2-{ }^{3} \mathrm{H}\right]$ glucose which occurred during the incubation. This will result in an underestimate of $R_{2}$ by about $4 \%$ under control conditions but by up to $35 \%$ in the presence of $1 \mathrm{~mm}-\alpha$-chlorohydrin; because of this effect the incubation time in succeeding experiments was restricted to a maximum of $30 \mathrm{~min}$.

The estimate of the rate of glycolysis from the release of tritiated water from $\left[3-{ }^{3} \mathrm{H}\right]$ glucose was very similar to the estimates made with $\left[2-{ }^{3} \mathrm{H}\right] \mathrm{glucose}$ except when $1.0 \mathrm{~mm}-\alpha$-chlorohydrin was present (Table 1). Here much less ${ }^{3} \mathrm{HOH}$ was released because the $\left({ }^{3} \mathrm{H} /{ }^{14} \mathrm{C}\right.$ ratio in fructose 1,6-bisphosphate) $\left({ }^{3} \mathrm{H} /{ }^{14} \mathrm{C}\right.$ ratio in glucose) $\left(\mathrm{S}_{2}\right)$ was $0 \cdot 85$, indicating that tritium was retained in fructose 1,6-bisphosphate. This was probably a consequence of the inhibition of triose phosphate isomerase [EC 5.3.1.1] by $\alpha$-chlorohydrin (Brown-Woodman et al., 1978; Ford \& Harrison, 1981). Accurate measurement of the isotope ratio in hexose phosphate $\left(S_{1}\right)$ was difficult in boar spermatozoa because of the low concentration of glucose 6-phosphate. Errors in $S_{1}$ become increasingly serious as $S_{2}$ becomes larger for this reason no further attempts were made to measure substrate cycling between fructose 6-phosphate and fructose 1,6-bisphosphate in boar spermatozoa.

\section{Time course of substrate cycling between glucose and glucose 6-phosphate in boar spermatozoa}

In the spermatozoa incubated with $\alpha$-chlorohydrin, ATP was converted to ADP and AMP and fructose 1,6-bisphosphate and triose phosphate accumulated (for an $\alpha$-chlorohydrin effect $P<0.001$ for all measures listed). The effect of $1.0 \mathrm{~mm}-\alpha$-chlorohydrin was significantly greater than that of $0.05 \mathrm{~mm}$ - $\alpha$-chlorohydrin $(P<0.002)$ but the difference was greatest in the first $20 \mathrm{~min}$ of the incubation (Fig. 2). The total adenine nucleotide concentration (ATP + ADP + AMP)

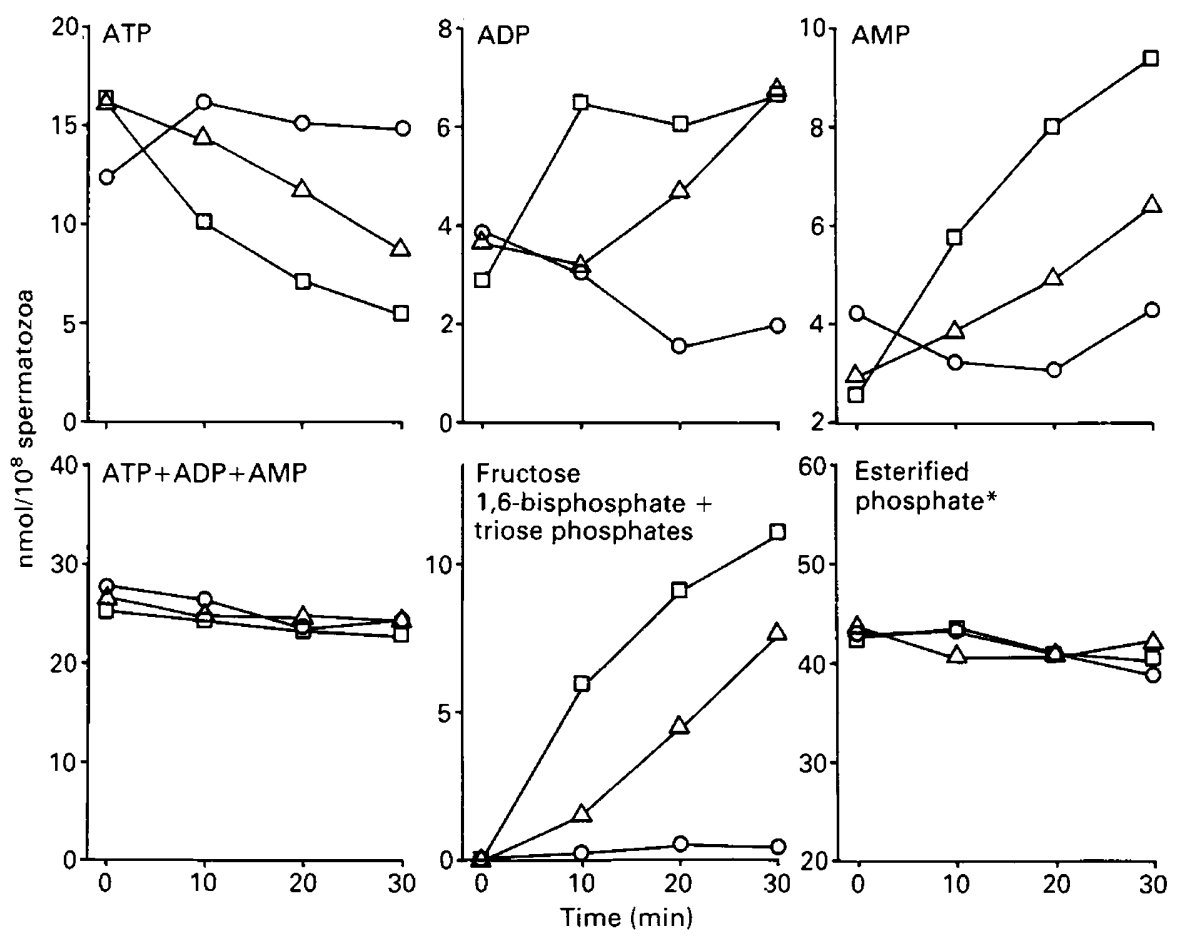

Fig. 2. The effect of $0(O), 0.05(\triangle)$ or $1.0(\square)$ mM- $\alpha$-chlorohydrin on the concentrations of adenine nucleotides and some glycolytic intermediates in boar spermatozoa incubated with 0.1 mM-glucose. Mean of 2 experiments. ${ }^{*}$ In the $\beta$ and $\gamma$ positions of ATP, the $\beta$ position of ADP and in glycolytic intermediates. 
remained remarkably constant and the amount of phosphate required for the synthesis of glycolytic intermediates exactly balanced the phosphate released by the conversion of ATP to ADP and AMP so that the amount of esterified phosphate did not change during the experiment (Fig. 2).

$\alpha$-Chlorohydrin blocked glucose metabolism and $15.4 \pm 3 \cdot 12,5.4 \pm 1.39$ and $0.6 \pm 0.13$ (mean \pm s.e.m.; $n=3$ ) nmol glucose were converted to lactate $+\mathrm{CO}_{2}$ in the presence of $0,0.05$ and $1.0 \mathrm{~mm}-\alpha$-chlorohydrin respectively (Table 2 ).

Table 2. The utilization of glucose measured by enzymic and radiochemical methods and the recovery of products after $30 \mathrm{~min}$ incubation of boar spermatozoa with $0 \cdot 1 \mathrm{~mm}-\left[2-{ }^{3} \mathrm{H}, \mathrm{U}-{ }^{14} \mathrm{C}\right]$ glucose in the presence of $\alpha$-chlorohydrin

\begin{tabular}{|c|c|c|c|}
\hline \multirow[b]{2}{*}{ Method or product } & \multicolumn{3}{|c|}{$\alpha$-chlorohydrin (mM) } \\
\hline & 0 & 0.05 & 1.00 \\
\hline $\begin{array}{l}\text { Glucose utilization HK.G6PDH } \dagger \\
-{ }^{14} \mathrm{C} \\
{ }^{3} \mathrm{H}\end{array}$ & $\begin{array}{l}23 \pm 0 \cdot 8 \\
19 \pm 3 \cdot 8 \\
26 \pm 4 \cdot 5\end{array}$ & $\begin{array}{l}22 \pm 1 \cdot 1 \\
15 \pm 1 \cdot 9 \\
24 \pm 3 \cdot 4\end{array}$ & $\begin{aligned} 23 & \pm 1 \cdot 7 \\
9 & \pm 1 \cdot 6 \\
22 & \pm 3.4\end{aligned}$ \\
\hline $\begin{array}{l}\text { Product formation } \\
\text { Tritiated water } \\
{\left[{ }^{14} \mathrm{C}\right] \text { Lactate }} \\
{\left[{ }^{14} \mathrm{C}\right] \text { Fructose } 1,6 \text {-bisphosphate }} \\
{\left[{ }^{14} \mathrm{C}\right] \text { Glucose 6-phosphate }} \\
{ }^{14} \mathrm{CO}_{2} \\
\text { Total }{ }^{14} \mathrm{C} \text { products }\end{array}$ & $\begin{array}{l}23 \pm 3.9 \\
15 \pm 2 \cdot 9 \\
0 \cdot 2 \pm 0.02 \\
1.6 \pm 0.3 \\
0.7 \pm 0.3 \\
17 \pm 3.3\end{array}$ & $\begin{aligned} 23 & \pm 3 \cdot 7 \\
5 & \pm 1 \cdot 3 \\
5 & \pm 0 \cdot 3 \\
2 & \pm 0 \cdot 3 \\
0 \cdot 5 & \pm 0 \cdot 11 \\
12 & \pm 1 \cdot 8\end{aligned}$ & $\begin{array}{l}23 \pm 4 \cdot 6 \\
0 \cdot 5 \pm 0 \cdot 09 \\
7 \pm 1 \cdot 0 \\
1 \cdot 5 \pm 0 \cdot 22 \\
0 \cdot 1 \pm 0 \cdot 04 \\
9 \pm 1 \cdot 2\end{array}$ \\
\hline
\end{tabular}

Results are nmol glucose metabolized $/ 10^{8}$ spermatozoa and are the mean \pm s.e.m. of 3 experiments.

†Enzymic assay with hexokinase and glucose 6-phosphate dehydrogenase.
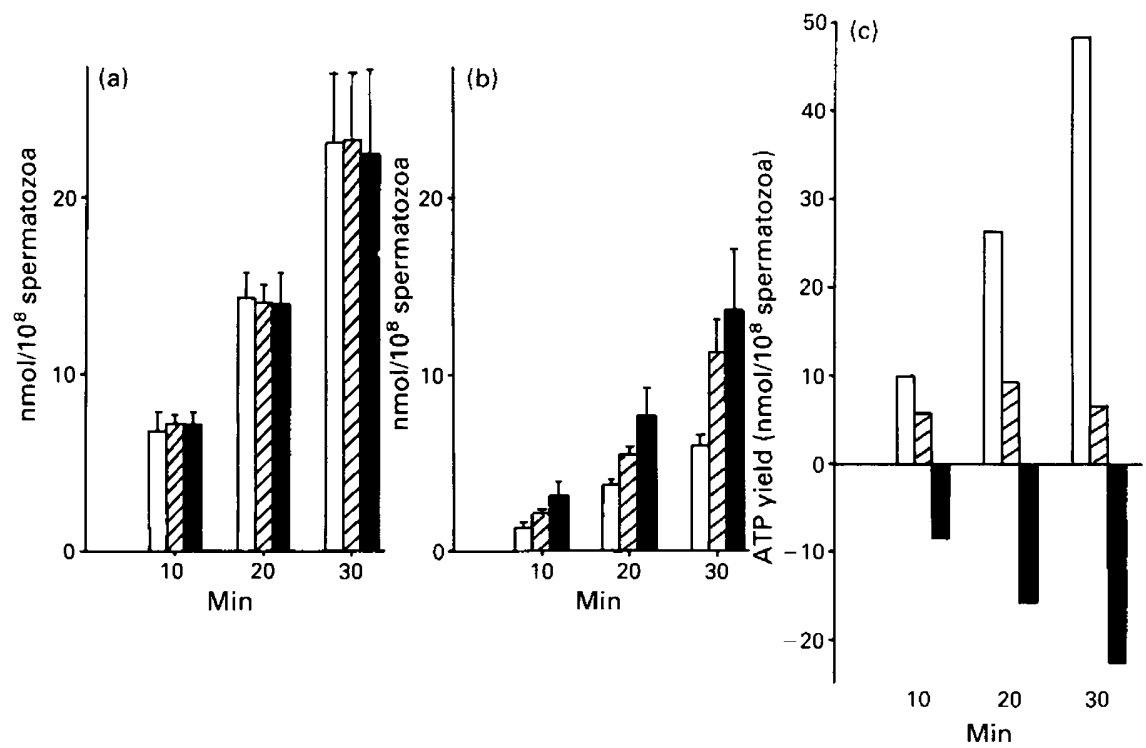

Fig. 3. The effect of $0(\square), 0.5(\mathbb{Z})$ or $1.0(\mathbb{a}) \mathrm{mm}-\alpha$-chlorohydrin on (a) tritium release from $\left[2-{ }^{3} \mathrm{H}\right]$ glucose (slope $=\mathbf{R}_{1}$ ) and (b) glucose 6-phosphate hydrolysis (slope $=\mathbf{R}_{2}$ ) and (c) the net ATP yield from glucose metabolism in boar spermatozoa incubated with $0 \cdot 1 \mathrm{mM}-\left[2-{ }^{3} \mathrm{H}, \mathrm{U}-{ }^{14} \mathrm{C}\right]-$ glucose. Values are mean \pm s.e.m. of 3 experiments except for $(c)$ which was calculated from the means of various parameters. 
The disappearance of $\left[2-{ }^{3} \mathrm{H}\right] \mathrm{glucose}$ agreed quite well with the rate of production of ${ }^{3} \mathrm{HOH}$ and the utilization of $\left[\mathrm{U}^{14} \mathrm{C}\right]$ glucose matched the rate of production of ${ }^{14} \mathrm{C}$-containing products (Table 2). The rate of release of ${ }^{3} \mathrm{HOH}\left(R_{1}\right)$ was constant with time and was not affected by $\alpha$-chlorohydrin (Fig. 3a). The rate of formation of ${ }^{14} \mathrm{C}$-labelled products was also constant with time but was significantly inhibited by $\alpha$-chlorohydrin. Therefore $\alpha$-chlorohydrin stimulated the rate of hydrolysis of hexosephosphates to sugars $\left(\mathrm{R}_{2}\right)\left(\mathrm{R}_{2} 1 \mathrm{~mm}-\alpha\right.$-chlorohydrin $>\mathrm{R}_{2}$ control, $P<0.001 ; \mathrm{R}_{2}$ 0.05 mM- $\alpha$-chlorohydrin $>\mathrm{R}_{2}$ control; $P<0.01$; analysis of variance; Fig. $3 \mathrm{~b}$ ). The decrease in the concentration of glucose measured in the enzymic assay was always very similar to the rate of release of ${ }^{3} \mathrm{HOH}$ from $\left[2-{ }^{3} \mathrm{H}\right]$ glucose but was larger than the disappearance of $\left[\mathrm{U}-{ }^{14} \mathrm{C}\right]$ glucose. The difference was small in the control incubations but large when $\alpha$-chlorohydrin was present (Table 2). Therefore, the glucose fraction also contains other sugars probably fructose derived from the hydrolysis of hexose phosphates and $\mathrm{R}_{2}{ }^{\prime \prime}$ and/or $\mathrm{R}_{2}{ }^{\prime \prime}$ (Fig. 1) make a significant contribution to $\mathrm{R}_{2}$ and this proportion is increased by $\alpha$-chlorohydrin.

Under control conditions boar spermatozoa produced about $50 \mathrm{nmol}$ ATP $/ 10^{8}$ spermatozoa/ $30 \mathrm{~min}$ from glucose metabolism and this was formed at a constant rate throughout the incubation. In the presence of $0.05 \mathrm{mM}-\alpha$-chlorohydrin, $<10 \mathrm{nmol}$ ATP $/ 10^{8}$ spermatozoa was produced and production ceased after the first $10 \mathrm{~min}$. In the presence of $1.0 \mathrm{~mm}-\alpha-$ chlorohydrin, $>20 \mathrm{nmol}$ ATP $/ 10^{8}$ spermatozoa were consumed in glucose metabolism (Fig. 3c).

The effect of $10 \mathrm{~mm}$-L-lactate plus $1 \mathrm{mM}$-pyruvate on glucose metabolism in boar spermatozoa incubated with $\alpha$-chlorohydrin

$\alpha$-Chlorohydrin at $1 \mathrm{~mm}$ inhibited the production of lactate from $0.1 \mathrm{~mm}$-glucose by $>90 \%$ (Fig. 4). This was accompanied by the accumulation of fructose 1,6-bisphosphate and a decline in
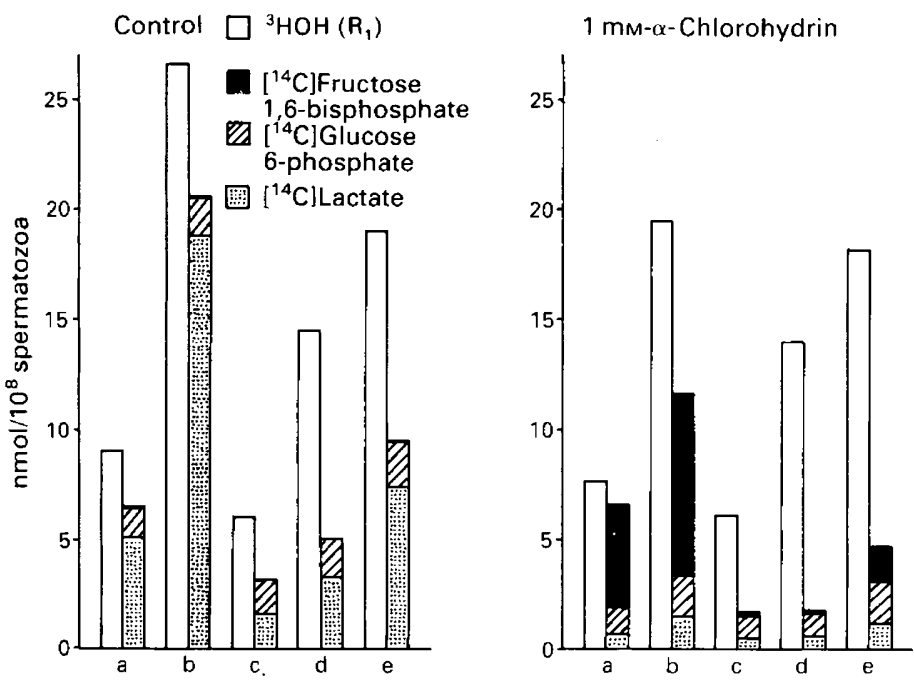

Fig. 4. The effect of $1 \mathrm{~mm}-\alpha$-chlorohydrin on the production of tritiated water, $\left[{ }^{14} \mathrm{C}\right]$ fructose 1,6-bisphosphate, $\left[{ }^{14} \mathrm{C}\right]$ glucose 6-phosphate (including some triose phosphates) and $\left[{ }^{14} \mathrm{C}\right]$ lactate from $0 \cdot 1 \mathrm{~mm}-\left[2-{ }^{3} \mathrm{H}\right]\left[\mathrm{U}-{ }^{14} \mathrm{C}\right]$ glucose added to boar spermatozoa at zero time: (a) no further addition $10 \mathrm{~min}$; (b) no further addition $30 \mathrm{~min}$; (c) $+10 \mathrm{~mm}$-L-lactate $+1 \mathrm{~mm}$ pyruvate at $0 \mathrm{~min}, 10 \mathrm{~min}$; (d) $+10 \mathrm{~mm}$-L-lactate $+1 \mathrm{~mm}$-pyruvate at $0 \mathrm{~min}, 30 \mathrm{~min}$; (e) $+10 \mathrm{~mm}$-L-lactate $+1 \mathrm{~mm}$-pyruvate at $10 \mathrm{~min}, 30 \mathrm{~min}$. All times are measured from the addition of glucose. Mean of 2 experiments. The rate of glucose 6-phosphate hydrolysis $\left(R_{2}\right)$ may be estimated from the difference in the heights of the clear and the sum of the hatched, stippled and solid columns. 
the ATP concentration (nmol/10 $10^{8}$ spermatozoa) after $30 \mathrm{~min}$ incubation from $17 \cdot 1(16 \cdot 1,18 \cdot 1)$ to $5 \cdot 4(5 \cdot 4,5 \cdot 3)$ (means of 2 experiments). $10 \mathrm{~mm}$-lactate plus $1 \mathrm{~mm}$-pyruvate decreased the production of $\left[{ }^{14} \mathrm{C}\right]$ lactate from $\left[\mathrm{U}-{ }^{14} \mathrm{C}\right]$ glucose but prevented the effect of $\alpha$-chlorohydrin on ATP and on fructose 1,6-bisphosphate. When $10 \mathrm{~mm}$-lactate plus $1 \mathrm{~mm}$-pyruvate was added $10 \mathrm{~min}$ after glucose the increase in fructose 1,6-bisphosphate concentration was largely reversed and the concentration of ATP increased from $8.6(8 \cdot 9,8 \cdot 3)$ after 10 min with glucose to $13.6(13 \cdot 4,13.7) 20$ min later. In contrast to the experiments described above $\alpha$-chlorohydrin decreased the rate of glucose phosphorylation $\left(\mathrm{R}_{1} ; P<0.01\right)$. Lactate $(10 \mathrm{mM})$ plus pyruvate $(1 \mathrm{~mm})$ also decreased $\mathrm{R}_{1}(P<0.001)$ but $\alpha$-chlorohydrin did not produce further inhibition when the additional substrates were present (Fig. 4). The rate of hexose phosphate hydrolysis $\left(\mathrm{R}_{2}\right)$ was not increased significantly by $\alpha$ chlorohydrin when $0.1 \mathrm{~mm}$-glucose was the only substrate present but was increased by $10 \mathrm{~mm}$ lactate plus 1 mm-pyruvate $(P<0 \cdot 05)$. $\alpha$-Chlorohydrin caused a further increase in $\mathrm{R}_{2}$ when lactate and pyruvate were present $(P<0.05)$ and the greatest value of $\mathrm{R}_{2}$ was seen when $10 \mathrm{~mm}$-lactate $+1 \mathrm{~mm}$-pyruvate were added to spermatozoa incubated with $1 \mathrm{~mm}$ - $\alpha$-chlorohydrin, $10 \mathrm{~min}$ after the glucose (Fig. 4).

\section{The effect of $\alpha$-chlorohydrin on the rate of futile substrate cycling in rat spermatozoa}

Rat spermatozoa incubated with $0.1 \mathrm{mm-glucose}$ accumulated a high concentration of glucose 6-phosphate and acetyl carnitine was a major product of $\left[\mathrm{U}-{ }^{14} \mathrm{C}\right]$ glucose metabolism. $\alpha$-Chlorohydrin at $1 \mathrm{~mm}$ inhibited the production of ${ }^{14} \mathrm{CO}_{2},\left[{ }^{14} \mathrm{C}\right]$ lactate and $\left[{ }^{14} \mathrm{C}\right]$ acetyl carnitine but promoted the accumulation of a high concentration of fructose 1,6-bisphosphate (Table 3). These changes were associated with a decline in the concentration of ATP from $21 \pm 3 \cdot 6$ to $6 \cdot 2 \pm 2 \cdot 4 \mathrm{nmol} 10^{8}$ spermatozoa (mean \pm s.e.m.).

Table 3. The effect of $1 \mathrm{~mm}-\alpha$-chlorohydrin on the metabolism of $\left[\mathrm{U}-{ }^{14} \mathrm{C}\right] \mathrm{glucose}$ by rat spermatozoa

\begin{tabular}{|c|c|c|}
\hline & \multicolumn{2}{|c|}{$\begin{array}{c}{\left[\mathrm{U}-{ }^{14} \mathrm{C}\right] \text { glucose converted to }} \\
{ }^{14} \mathrm{C} \text { product }\left(\mathrm{nmol} / 10^{8} \text { spermatozoa } / 30 \mathrm{~min} \text { ) }\right.\end{array}$} \\
\hline & Control & I mM-a-Chlorohydrin \\
\hline Total & $65 \cdot 0 \pm 11 \cdot 70$ & $46 \cdot 0 \pm 6 \cdot 40$ \\
\hline $\mathrm{CO}_{2}$ & $13 \cdot 4 \pm 2 \cdot 50$ & $2 \cdot 8 \pm 0.73^{* *}$ \\
\hline Acetyl carnitine & $11.9 \pm 2.84$ & $2 \cdot 6 \pm 0.83^{*}$ \\
\hline Lactate & $18.8 \pm 4.20$ & $6 \cdot 0 \pm 1 \cdot 14^{*}$ \\
\hline Glucose 6-phosphate† & $18.8 \pm 3.86$ & $15 \cdot 5 \pm 2 \cdot 36$ \\
\hline Fructose 1,6-bisphosphate & $1.7 \pm 0.38$ & $19 \cdot 0 \pm 3 \cdot 09 * *$ \\
\hline
\end{tabular}

Values are mean \pm s.e.m. for 6 experiments.

$\dagger$ Includes some triose phosphates.

${ }^{*} P<0.05 ;{ }^{* *} P<0.01$ compared with control value (2-way analysis of variance).

The measured rates of radioactive glucose utilization were not significantly different from the rates of production of radioactive products and for the experiments with $\left[3-{ }^{3} \mathrm{H}, \mathrm{U}-{ }^{14} \mathrm{C}\right] \mathrm{glucose}$ the rate of metabolism was nearly the same for each isotope (Table 4). Glucose 6-phosphate derived from $\left[2-{ }^{3} \mathrm{H}, \mathrm{U}-{ }^{14} \mathrm{C}\right]$ glucose contained no tritium, and this was checked by dividing the total tritium content of the crude glucose 6-phosphate fraction by the glucose 6-phosphate concentration determined enzymically; the maximum ${ }^{3} \mathrm{H}$ specific activity was $<4 \%$ that of glucose.

The relative specific activity of glucose 6-phosphate derived from $\left[3-{ }^{3} \mathrm{H}, \mathrm{U}-{ }^{14} \mathrm{C}\right]$ glucose $\left(\mathrm{S}_{1}\right)$ was 0.85 under control conditions and 0.72 in the presence of $1 \mathrm{~mm}$-chlorohydrin. The relative specific activity of fructose 1,6-bisphosphate derived from $\left[3-{ }^{3} \mathrm{H}, \mathrm{U}-{ }^{14} \mathrm{C}\right] \mathrm{glucose}\left(\mathrm{S}_{2}\right)$ could not be measured 
Table 4. The effect of $1 \mathrm{~mm}-\alpha$-chlorohydrin on the utilization of glucose and the formation of products by rat spermatozoa in a 30 -min incubation at $34^{\circ} \mathrm{C}$

\begin{tabular}{|c|c|c|c|c|c|}
\hline & \multirow{2}{*}{$\begin{array}{l}\alpha \text {-Chlorodhydrin } \\
(\mathrm{mM})\end{array}$} & \multicolumn{2}{|c|}{ 'Glucose' utilization } & \multicolumn{2}{|c|}{ Product formation } \\
\hline & & {$\left[\mathrm{U}-{ }^{14} \mathrm{C}\right]-$} & {$\left[2-\right.$ or $\left.3-{ }^{3} \mathrm{H}\right]-$} & ${ }^{14} \mathrm{C}$ & ${ }^{3} \mathrm{HOH}$ \\
\hline \multirow{3}{*}[3-{}^{3}\mathrm{H},\mathrm{U}-{}^{14}\mathrm{C}]{ glucose } & 0 & $76 \pm 18 \cdot 7$ & $75 \pm 18 \cdot 5$ & $68 \pm 22 \cdot 3$ & $65 \pm 16 \cdot 1$ \\
\hline & 1.0 & $54 \pm 5 \cdot 2$ & $58 \pm 2 \cdot 4$ & $48 \pm 2.9$ & $48 \pm 3 \cdot 2$ \\
\hline & 0 & $72 \pm 13 \cdot 0$ & $79 \pm 11.9$ & $61 \pm 13.4$ & $72 \pm 12.8$ \\
\hline$\left\{2-{ }^{3} \mathrm{H}, \mathrm{U}-{ }^{14} \mathrm{C}\right]$ glucose & 1.0 & $46 \pm 10.9$ & $57 \pm 13.8$ & $44 \pm 13.9$ & $54 \pm 16 \cdot 1$ \\
\hline
\end{tabular}

Values are nmol glucose metabolized $/ 10^{8}$ spermatozoa and are mean \pm s.e.m. of 3 observations.

Table 5. The effect of $\alpha$-chlorohydrin on the forward and reverse flux through two potential substrate cycles in rat spermatozoa

\begin{tabular}{lcc}
\hline Cycle & Control & 1 mM- $\alpha$-Chlorohydrin \\
\hline Glucose 6-phosphate & & \\
Synthesis $\left(\mathrm{R}_{1}\right)$ & $72 \pm 12 \cdot 8$ & $54 \pm 16 \cdot 1$ \\
Hydrolysis $\left(\mathrm{R}_{2}\right)$ & $11 \pm 2 \cdot 9$ & $10 \pm 2 \cdot 4$ \\
Fructose 1,6-bisphosphate & & \\
$\quad$ Synthesis $\left(\mathrm{R}_{3}\right)$ & $76 \pm 18 \cdot 9$ & $72 \pm 5 \cdot 3$ \\
Hydrolysis $\left(\mathrm{R}_{4}\right)$ & $11 \pm 2 \cdot 8$ & $24 \pm 1 \cdot 6^{* * *}$ \\
\hline
\end{tabular}

Values are $\mathrm{nmol} / 10^{8}$ spermatozoa $/ 30 \mathrm{~min}$ and are mean \pm s.e.m. for 3 observations.

* $P<0.001$ compared with control (2-way analysis of variance).

Table 6. The effect of $\alpha$-chlorohydrin on the ATP yield $\left(\mathrm{nmol} / 10^{8}\right.$ spermatozoa/30 $\mathrm{min}$ ) from glucose metabolism in rat spermatozoa

\begin{tabular}{lcc}
\hline & Control & $\begin{array}{c}1 \text { mM- } \alpha \text { - } \\
\text { Chlorohydrin }\end{array}$ \\
\hline ATP yield from production of & 34 & 12 \\
$\quad$ Lactate & 250 & 54 \\
Acetyl carnitine & 286 & 50 \\
CO & 570 & 116 \\
Gross ATP production & & \\
ATP consumed in glucose metabolism: & & 7 \\
In synthesis of: & $0 \cdot 2$ & 35 \\
$\quad$ Glucose 6-phosphate & 12 & 22 \\
$\quad$ Fructose 1,6-bisphosphate & & \\
$\quad$ Triose phosphate & 11 & 10 \\
In futile cycles: & 11 & 24 \\
$\quad$ Glucose 6-phosphate hydrolysis $\left(\mathrm{R}_{2}\right)$ & 46 & 97 \\
$\quad$ Fructose 1,6-bisphosphate hydrolysis $\left(\mathbf{R}_{\mathbf{4}}\right)$ & 524 & 19 \\
Total ATP cost & & \\
Net yield from glucose & & \\
\hline
\end{tabular}

under control conditions because of its low concentration and was assumed to be zero; in the presence of $\alpha$-chlorohydrin it was $0 \cdot 15$.

The rates $\left(\mathrm{nmol} / 10^{8}\right.$ spermatozoa $\left./ 30 \mathrm{~min}\right)$ of phosphorylation of glucose $\left(\mathrm{R}_{1}\right)$ and of fructose 6-phosphate $\left(R_{3}\right)$ were both about 70 under control conditions whilst the rates of hydrolysis of hexose phosphate to hexose and of fructose 1,6-bisphosphate to fructose 6-phosphate $\left(R_{2}\right.$ and $\left.R_{4}\right)$ were about 10 (Table 5). In the incubations with $\alpha$-chlorohydrin, $R_{1}$ and $R_{3}$ did not change significantly but there was a significant $(P<0.001)$ increase in $\mathrm{R}_{4}$ (Table 5). The data were used to 
calculate the ATP yield from glucose metabolism. Under control conditions $>30 \%$ of the gross ATP production was derived from acetyl carnitine synthesis but most ATP came from the complete oxidation of glucose to $\mathrm{CO}_{2}$. The consumption of ATP in futile substrate cycles was $>60 \%$ of the ATP synthesized in lactate prodution but only about $5 \%$ of the gross yield (Table 6 ).

$\alpha$-Chlorohydrin at $1 \mathrm{~mm}$ decreased the net ATP yield to $<5 \%$ of the control rate. The greatest effect was in preventing ATP synthesis but an extra $45 \mathrm{nmol}$ ATP was consumed in the production of fructose 1,6-bisphosphate and triose phosphate and an extra $10 \mathrm{nmol}$ ATP in futile substrate cycling (Table 4).

\section{Discussion}

The data described above indicate that it is highly probable that the hydrolysis of fructose phosphates to fructose makes a significant contribution to ATP dissipation in the early steps of the glycolytic pathway in boar spermatozoa. Fructose formation is increased by $\alpha$-chlorohydrin. $\alpha$-Chlorohydrin did not increase the concentration of glucose 6-phosphate to a large extent and is therefore unlikely to have any large effect on the concentration of fructose 6-phosphate but it did cause a very large increase in the concentration of fructose 1,6-bisphosphate. Therefore it is probable that the additional fructose arose by the formation of fructose 1-phosphate and its subsequent hydrolysis. Each mole recycled by this route would consume 2 rather than 1 mol ATP. At maximum this would increase the moles of ATP dissipated during $30 \mathrm{~min}$ incubation of boar spermatozoa with $1 \mathrm{~mm}-\alpha$-chlorohydrin from 14 to 28 because the discrepancy between ${ }^{3} \mathrm{HOH}$ formation and ${ }^{14} \mathrm{C}$ product formation is entirely accounted for by the difference between glucose utilization and $\left[\mathrm{U}-{ }^{14} \mathrm{C}\right]$ hexose disappearance (i.e. fructose formation) (Table 2).

The low concentration of glucose 6-phosphate in boar spermatozoa precluded the measurement of its isotope ratio and there is no way to confirm that the assumption that all the tritium was lost was valid. Fortunately, considerable isotope retention is required to have a large effect on the results, e.g. for the data in Table 1 the rate of hexose phosphate hydrolysis $\left(R_{2}\right)$ in the presence of $1 \mathrm{~mm}$ - $\alpha$-chlorohydrin would be $22,26,35,53$ or $105 \mathrm{nmol} / 10^{8}$ spermatozoa/ $\mathrm{h}$ if the relative specific activity of glucose 6-phosphate was taken as $0,0 \cdot 2,0.4,0.6$ and 0.8 respectively. A large error is unlikely because of the agreements between the glycolytic rate under control conditions calculated from measurements made with $\left[2-{ }^{3} \mathrm{H}\right]$ - and with $\left[3-{ }^{3} \mathrm{H}\right]$-glucose and the general agreement between the rates of glucose disappearance and of product formation (Tables 1 and 2).

The isotope ratio in glucose 6-phosphate and in fructose 1,6-bisphosphate could be measured in rat spermatozoa except for fructose 1,6-bisphosphate in the control incubations. It is clear that ${ }^{3} \mathrm{H}$ was effectively completely lost from $\left[2-{ }^{3} \mathrm{H}\right]$ glucose 6 -phosphate and the procedure used to calculate $\mathrm{R}_{2}$ is justified. This also demonstrates that glucose 6-phosphate must be in rapid equilibrium with fructose 6-phosphate. It is very unlikely that more tritium from $\left[3-{ }^{3} \mathrm{H}\right]$ glucose would be retained in fructose 1,6-bisphosphate under control conditions than in the presence of $\alpha$-chlorohydrin, and on this basis the maximum error from the assumption that all the tritium was lost will be about $18 \%$. Fructose 1-phosphate hydrolysis does not occur to a significant extent in rat spermatozoa because there is no change in the isotope ratio of 'glucose' in the incubations with $\left[3-{ }^{3} \mathrm{H}, \mathrm{U}-{ }^{14} \mathrm{C}\right] \mathrm{glucose}$ with or without $\alpha$-chlorohydrin. The route through fructose I-phosphate would lead to a relative depletion of ${ }^{3} \mathrm{H}$ in the hexose pool because the ${ }^{3} \mathrm{H} /{ }^{14} \mathrm{C}$ ratio in the fructose 1,6-bisphosphate pool was $\leqslant 0 \cdot 15$. The formation of fructose 1 -phosphate as a dead-end metabolite cannot be ruled out but the maximum extent of this can be calculated from the difference between the concentrations of the chromatographically identified hexose phosphate fraction, and glucose 6-phosphate determined enzymically; this was 7.3 and $7.7 \mathrm{nmol} / 10^{8}$ spermatozoa/30 $\mathrm{min}$ in controls and in the presence of $1 \mathrm{mM}-\alpha$-chlorohydrin respectively, but these figures are an overestimate because they include triose phosphate which elutes in the hexose phosphate fraction. 
It is unlikely that extensive hydrolysis of triose phosphates occurred through the activity of non-specific phosphatases. The ${ }^{14} \mathrm{C}$-labelled products would only bind weakly to the Dowex 1 borate column and would be eluted in the ${ }^{3} \mathrm{HOH}$ fraction. Very little ${ }^{14} \mathrm{C}$ was recovered in this fraction and the proportion was not increased by $\alpha$-chlorohydrin.

The potential errors discussed above would lead to an underestimate of the rate of futile substrate cycling and it is clear that this process could consume a large proportion of the ATP synthesized by substrate level phosphorylation during glycolysis to lactate in rat and in boar spermatozoa. The ATP consumption remains a small fraction of the ATP synthesis from oxidative phosphorylation and it may be that the glycolytic pathway in these cells acts principally as a source of pyruvate for mitochondrial respiration, as has been suggested for bull spermatozoa (Hammerstedt \& Lardy, 1983; Inskeep \& Hammerstedt, 1985). It remains unlikely that futile substrate cycling has a vital role in sperm function but it may play some part in metabolic regulation because the decrease in net glycolytic flux caused by the presence of pyruvate and lactate was achieved by an increase in futile substrate cycling rather than a decrease in the phosphorylation of glucose by hexokinase (Fig. 4).

In boar and in rat spermatozoa, $\alpha$-chlorohydrin increased the rate of futile substrate cycling, but the significance of this must be assessed in the context of the rate of ATP turnover in the cells. In boar and in rat spermatozoa the respiration of endogenous substrates produces 240 and $270 \mathrm{nmol}$ ATP $/ 10^{8}$ spermatozoa/30 min based on oxygen uptakes of 1.3 and $1.5 \mathrm{nmol} \mathrm{O} \mathrm{O}_{2} / 10^{8}$ spermatozoa/min respectively (Ford, 1981) and P:O ratio (moles of ATP synthesized per atom of oxygen consumed) of 3 . The rate of oxygen uptake can be increased considerably by uncoupling agents or by stimulating the motility of the cells with caffeine and it is likely that a considerable increase in ATP turnover could be accommodated without a severe decline in its concentration. In the absence of glucose endogenous respiration is not inhibited by $\alpha$-chlorohydrin (W. C. L. Ford \& A. Harrison, unpublished results). The energy cost of glucose metabolism was considerably increased by $\alpha$-chlorohydrin because of the synthesis of large concentrations of glycolytic intermediates and the increase in futile cycling. Thus the synthesis of ATP was decreased to a very low amount and the net effect of glucose metabolism was to consume a small amount of ATP (boar) or to produce a negligible amount (rat) (Fig. 3; Table 6). The loss of ATP due to glucose metabolism was never $>10 \%$ of the estimated ATP turnover and the spermatozoa would normally be able to respond to such a demand by increasing the rate of mitochondrial respiration. Futile substrate cycling consumed less ATP than did the synthesis of glycolytic intermediates and large errors in its estimation would be needed to modify these conclusions. Furthermore, futile substrate cycling in boar spermatozoa was increased by lactate plus pyruvate which protected the ATP concentration in the spermatozoa. Therefore futile substrate cycling of glucose 6-phosphate and fructose 1,6bisphosphate cannot explain the concerted effect of $\alpha$-chlorohydrin and glucose on spermatozoa.

These results shed new light on the observation that triose phosphate isomerase is inhibited in ram spermatozoa incubated with $\alpha$-chlorohydrin (Brown-Woodman et al., 1978) or in rat spermatozoa from rats treated with 6-chloro-6-deoxyglucose (Ford \& Harrison, 1981), This effect has been given much less attention than the inhibition of glyceraldehyde 3-phosphate dehydrogenase but the extensive retention of ${ }^{3} \mathrm{H}$ from $\left[3-{ }^{3} \mathrm{H}\right]$ glucose in fructose 1,6-bisphosphate in boar spermatozoa in the presence of $\alpha$-chlorohydrin (Table 1 ) demonstrates that it can markedly affect metabolism. It is unclear why such retention of ${ }^{3} \mathrm{H}$ was not observed in rat spermatozoa.

If futile substrate cycling cannot explain the effect of $\alpha$-chlorohydrin and glucose then an alternative explanation must be sought. One possibility is that they act together to inhibit respiration; some evidence to support this has already been produced (Ford \& Harrison, 1986) and glucose decreases the rate of respiration and of phospholipid utilization in bull spermatozoa (Lardy \& Philips, 1941). This might be brought about by the transfer of phosphate from the adenine nucleotide pool to glycolytic intermediates. It is striking that the phosphate released by the hydrolysis of ATP to ADP and AMP so exactly matches the amount of phosphate esterified in the production of glycolytic intermediates (Fig. 2). A decrease in the supply of inorganic phosphate for oxidative phosphorylation has been claimed to explain the inhibition of respiration by glucose in ascites 
tumour cells incubated with iodoacetate (Gatt \& Racker, 1959). The uptake of phosphate by bull spermatozoa is restricted and the intracellular concentration is about $25 \mathrm{nmol} / 10^{8}$ spermatozoa (Babcock et al., 1975). It is possible that the concentration of inorganic phosphate and ADP in spermatozoa in the presence of $\alpha$-chlorohydrin and glucose could be sufficient to allow respiration to proceed without a dramatic degree of inhibition but that the total amount of phosphate in the spermatozoa could be too little to allow the ATP consumed in the production of glycolytic intermediates to be replaced.

This work was supported by Grant No. G822472SB from the Medical Research Council.

\section{References}

Babcock, D.F., First, N.L. \& Lardy, H.A. (1975) Transport mechanism for succinate and phosphate localized in the plasma membrane of bovine spermatozoa. J. biol. Chem. 250, 6488-6495.

Brown-Woodman, P.D.C., Mohri, H., Mohri, T., Suter, D. \& White, I.G. (1978) Mode of action of $\alpha$ chlorohydrin as an antifertility agent. Biochem. $J$. 170, 23-37.

Ford, W.C.L. (1981) The oxidation of glycerol 3phosphate by testicular and epididymal spermatozoa. Comp. Biochem. Physiol. 68B, 289-293.

Ford, W.C.L. (1982) The mode of action of 6-chloro6-deoxysugars as antifertility agents in the male. Current Topics Reprod. Endocrinol. 2, 159-184.

Ford, W.C.L. \& Harrison, A. (1981) The effect of 6-chloro-6-deoxysugars on adenine nucleotide concentrations in and the motility of rat spermatozoa. J. Keprod. Fert. 63, 75-79.

Ford, W.C.L. \& Harrison, A. (1985) The presence of glucose increases the lethal effect of $\alpha$-chlorohydrin on ram and boar spermatozoa in vitro. J. Reprod. Fert. 73, 197-206.

Ford, W.C.L. \& Harrison, A. (1986) The concerted effect of $\alpha$-chlorohydrin and glucose on the ATP concentration in spermatozoa is associated with the accumulation of glycolytic intermediates. $J$. Reprod. Fert. 77, 537-545.

Ford, W.C.L., Harrison, A. \& Waites, G.M.H. (1981) Effects of 6-chloro-6-deoxysugars on glucose oxidation in rat spermatozoa. J. Reprod. Fert. 63, 67-73.

Gatt, S. \& Racker, E. (1959) Regulatory mechanisms in carbohydrate metabolism. 1. Crabtree effect in reconstructed systems. J. biol. Chem. 234, 1015-1023.
Hammerstedt, R.H. (1980) A rapid method for isolating glucose metabolites involved in substrate cycling. Analyt. Biochem. 109, 443-448.

Hammerstedt, R.H. \& Lardy, H.A. (1983) The effect of substrate cycling on the ATP yield of sperm glycolysis. J. biol. Chem. 258, 8759-8768.

Hoskins, D.D. \& Stephens, D.T. (1969) Regulating properties of primate sperm phosphofructokinase. Biochem. Biophys. Acta 191, 292-302.

Hue, L. (1981) The role of futile cycles in the regulation of carbohydrate metabolism in the liver. $A d v$. Enzymol. 52, 249-331.

Inskeep, P.B. \& Hammerstedt, R.H. (1985) Endogenous metabolism by sperm in response to altered cellular ATP requirements. $J$. cell. Physiol. 123, 180-190.

Jones, R. (1983) Antifertility actions of $\alpha$-chlorohydrin in the male. Aust. J. biol. Sci. 36, 333-350.

Katz, J. \& Rognstad, R. (1976) Futile cycles in the metabolism of glucose. Curr. Topics Cell. Reg. 10, 238-289.

Lardy, H.A. \& Philips, P.H. (1941) The interrelation of oxidative and glycolytic processes as sources of energy for bull spermatozoa. Am. J. Physiol. 133, 602-609.

Newsholme, E.A. \& Crabtree, B. (1976) Substrate cycles in metabolic regulation and in heat generation. Biochem. Soc. Symp. 41, 61-109.

Newsholme, E.A., Arch, J.R.S., Brooks, B. \& Surhold, B. (1983) The role of substrate cycles in metabolic regulation. Biochem. Soc. Trans. 11, 52-56.

Received 21 March 1986 